\title{
Influence of Management on Soil Organic Carbon Dynamics in Northern Mixed-Grass Rangeland
}

\section{G.E. Schuman}

High Plains Grasslands Research Station, Cheyenne, WY

\section{L.J. Ingram and P.D. Stahl}

Department of Renewable Resources, University of Wyoming, Laramie, WY

\section{J.D. Derner}

High Plains Grasslands Research Station, Cheyenne, WY

\section{G.F. Vance}

Department of Renewable Resources, University of Wyoming, Laramie, WY

\section{J.A. Morgan}

Crops Research Laboratory, Fort Collins, CO

Effects of livestock grazing on rangeland soil organic carbon (SOC) dynamics have been variable and inconsistent among the ecosystems studied (Smoliak et al., 1972; Bauer et al., 1987; Milchunas and Lauenroth, 1993; Frank et al., 1995). Studies have shown that grazing affects SOC levels, either through changes in plant community (Coupland et al., 1960; Dormaar and Willms, 1990; Coupland, 1992) or by other more subtle and less discernable responses such as litter accumulation and decomposition rates, changes in chemical composition of soil organic matter (SOM), amount and quality of root exudates, increased root biomass, and more rapid cycling of C (Schuster, 1964; Smoliak et al., 1972; Dyer and Bokhari, 1976; Davidson, 1978; Christie, 1979; Detling et al., 1979; Holland and Detling, 1990; Naeth et al., 1991; Shariff et al., 1994; Ganjegunte et al., 2005). The quantity and chemical composition of SOM is important to $\mathrm{C}$ and $\mathrm{N}$ cycling, as $\mathrm{N}$ is often the limiting factor to productivity in rangeland ecosystems (Power, 1994).

Understanding grazing management effects on SOC accumulation and chemical composition is important to provide effective soil $\mathrm{C}$ management options for rangelands (Kaiser, 2000). Impacts of grazing on the distribution of soil C between labile and recalcitrant pools are also important to understand $C$ storage potentials in rangelands (Parton et al., 2000). If grazing results in greater incorporation of organic matter into recalcitrant soil C pools, then grazing may enhance

Soil Carbon Sequestration and the Greenhouse Effect, 2nd edition. SSSA Special Publication 57. Copyright (C) 2009. ASA-CSSA-SSSA, 677 S. Segoe Rd., Madison, WI 53711, USA. 
long-term soil C storage. Environmental conditions such as drought and climate change also influence $C$ sequestration (Jones and Donnelly, 2004).

Research conducted at the High Plains Grasslands Research Station near Cheyenne, Wyoming, on a northern mixed-grass prairie has addressed the role of grazing and climatic conditions on $\mathrm{C}$ cycling and the sustainability of this rangeland ecosystem. Specifically, investigators have evaluated the effects of three grazing intensities and climatic conditions on SOC (Ganjegunte et al., 2005), plant-soil system C balance (Schuman et al., 1999; Ingram et al., 2008), and soil respiration and photosynthesis (LeCain et al., 2000). This chapter summarizes the effects of grazing management and climatic conditions on the potential for $\mathrm{C}$ sequestration by a mixed-grass ecosystem.

\section{Site Description and Methods}

Research was conducted on a native northern mixed-grass rangeland near Cheyenne, Wyoming (lat. $41^{\circ} 11^{\prime} \mathrm{N}$, long. $104^{\circ} 54^{\prime} \mathrm{W}$ ), which has a rolling topography, elevation ranging from 1910 to $1950 \mathrm{~m}$, a 127-d growing season, and an average annual precipitation of $384 \mathrm{~mm}$, of which $70 \%$ occurs from 1 April through 30 September (NOAA, 1994). Soils are primarily Ascalon sandy loams (mixed, mesic, Aridic Argiustolls) (Stevenson et al., 1984). Vegetation on the High Plains Grasslands Research Station is predominately comprised of grasses (55\% cool-season $\left[\mathrm{C}_{3}\right]$ species and $23 \%$ warm-season $\left[\mathrm{C}_{4}\right]$ species), forbs, sedges, and half-shrubs. Dominant grasses are $\mathrm{C}_{3}$, western wheatgrass [Pascopyrum smithii (Rydb.) A. Love] and needleandthread [Hesperostipa comata (Trin \& Rupr.) Barkworth], and $\mathrm{C}_{4}$, blue grama [Bouteloua gracilis (H.B.K.) Lag. Ex Steud.]. The study area had not been grazed by domestic livestock for more than $40 \mathrm{yr}$ before establishment of grazing treatments in 1982.

Three treatments were imposed: (i) nongrazed 0.2-ha exclosures, EX; (ii) continuous season-long light grazing ( 0.16 to 0.23 steers ha $\left.^{-1}\right), \mathrm{CL}$; and (iii) continuous, season-long heavy grazing ( 0.56 steers ha $\left.{ }^{-1}\right), \mathrm{CH}$. The $\mathrm{CL}$ and $\mathrm{CH}$ pastures were 41 and 9 ha, respectively. The experiment was a randomized block design with two replicate blocks (pastures). Details of the grazing treatments and pasture design are given by Hart et al. (1988).

Transects $(50 \mathrm{~m})$ were established in each replicate pasture on near-level sites of Ascalon soil series. Depth of the A horizon and solum of the Ascalon soil is 15 \pm 2 and $100 \pm 7 \mathrm{~cm}$, respectively. In July 1993, soil and plant samples were collected at $10-\mathrm{m}$ intervals along transects to assess $C$ content of the various plant-soil system components. Soil samples were collected to a depth of $60 \mathrm{~cm}$ and segregated into the following depth increments: 0 to 3.8, 3.8 to $7.6,7.6$ to 15,15 to 30,30 to 45 , and 45 to $60 \mathrm{~cm}$. Soil organic $C$ was determined using the Walkley-Black dichromate oxidation procedure (Nelson and Sommers, 1982), and plant-component $C$ was determined with an automated combustion analyzer (NA2100 Protein, Carla-Erba Instruments, Italy). ${ }^{1}$

Separate soil cores were obtained for root biomass and C assessment. Bulk density data were obtained and used to convert the soil $\mathrm{C}$ concentrations determined on a mass concentration basis $\left(\mathrm{mg} \mathrm{kg}^{-1}\right)$ to mass of $C$ on a land area basis $\left(\mathrm{Mg} \mathrm{ha}^{-1}\right)$. Bulk density samples were collected using a 3.2-cm diameter core,

${ }^{1}$ Brand names and company identification are made for the benefit of the reader only and in no way imply endorsement by USDA or the Agricultural Research Service. 
which was $3.8 \mathrm{~cm}$ long for the first two depth increments and $7.6 \mathrm{~cm}$ long for the lower four depths (Blake and Hartge, 1986). Root biomass was obtained using a washing and screening technique described by Lauenroth and Whittman (1971) and air elutriation. Surface litter and standing dead plant biomass were estimated at $10-\mathrm{m}$ increments along the transects within an $0.18-\mathrm{m}^{2}$ quadrat. Estimates of annual production were obtained from duplicate $0.18-\mathrm{m}^{2}$ quadrats clipped from three $2.25-\mathrm{m}^{2}$ temporary exclosures located in each grazed pasture. Within the EX treatments, five $0.18-\mathrm{m}^{2}$ quadrats were sampled along the $50-\mathrm{m}$ transects.

In 1995, five 1- $\mathrm{m}^{2}$ angle iron metal frames were driven into the soil about 3 $\mathrm{m}$ from and parallel to each 50-m transect for assessing system total carbon dioxide $\left(\mathrm{CO}_{2}\right)$ exchange rates $\left(\mathrm{CER}_{\mathrm{T}}\right)$, a combined measure of photosynthetic activity and soil respiration. The $\mathrm{CER}_{\mathrm{T}}$ measurements were made only on one replicate pasture of each treatment. The CER $\mathrm{T}_{\mathrm{T}}$ was measured with a $40-\mathrm{cm}$ high by $100-\times$ $100-\mathrm{cm}$ Lexan (Regal Plastics, Littleton, CO) chamber. The air in the chamber was circulated by small fans and a sample pumped to a portable infrared analyzer that assessed the $\mathrm{CO}_{2}$ depletion within the chamber during a 2- to 3-min period. The $\mathrm{CER}_{\mathrm{T}}$ measurements were taken from 1000 to $1300 \mathrm{~h}$ (Mountain Standard Time) about every 3 wk during the growing seasons of 1995 through 1997. Measurements made on the treatment sites showed that maximum daily $\mathrm{CER}_{\mathrm{T}}$ occurred during 1000- to 1300-h period of the day, which agrees with Detling et al. (1979). Each time $\mathrm{CER}_{\mathrm{T}}$ measurements were made, a point frame was used to determine the green vegetation index (GVI) within each of the CER frames (Warren-Wilson, 1963). Standard methods of assessing leaf area index would not work on a plant canopy of this short stature, and destructive sampling was unacceptable to achieve repeated sampling through time on the same areas. Soil respiration was assessed on small plots $\left(82 \mathrm{~cm}^{2}\right)$ adjacent to each CER frame in which all vegetation had been removed (PP Systems, SRC-1, Hertfordshire, UK). Rates of soil respiration were subtracted from $\mathrm{CER}_{\mathrm{T}}$ values to estimate photosynthesis CER, designated CER. Greater details of these studies are reported by Schuman et al. (1999) and LeCain et al. (2000).

In 2003, soil samples were collected from the grazing treatment transects to assess the long-term effects of grazing and climate on SOC storage and composition. Samples were again collected to $60 \mathrm{~cm}$. Total soil $\mathrm{C}$ was determined using a C/N analyzer (NA2100 Protein, Carla-Erba Instruments, Italy). Soil inorganic $\mathrm{C}$ was determined using a modified pressure-calcimeter method (Sherrod et al., 2002), and SOC was calculated by subtracting inorganic $C$ from total C. Lignin characterization of the 2003 samples was conducted on $<2-\mathrm{mm}$ soil material and humic fractions using the alkaline cupric oxide $(\mathrm{CuO})$ oxidation modified method developed by Kögel and Böchter (1985) and Kögel-Knabner et al. (1991). Lignin oxidation products were separated using C18 solid-phase extraction disposable columns (Alltech, Deerfield, IL) followed by HPLC analysis (Ganjegunte et al., 2005). Duplicate soil bulk density samples were collected along each transect, and these data were used to calculate SOC mass. The SOC mass found in 2003 under these grazing treatments was compared to analogous soil data collected in 1993.

\section{Results and Discussion}

Grazing of these pastures for $12 \mathrm{yr}$ at the heavy stocking rate decreased peak standing crop (PSC) (Table 11-1) and shifted plant composition. Western 
Table 11-1. Total above- and belowground vegetation biomass as affected by grazing in 1993. (Modified from Schuman et al., 1999.)

\begin{tabular}{|c|c|c|c|c|}
\hline Component & Exclosure & $\begin{array}{c}\text { Continuous } \\
\text { light grazing }\end{array}$ & $\begin{array}{l}\text { Continuous } \\
\text { heavy grazing }\end{array}$ & $\operatorname{LSD}(0.10)$ \\
\hline & & $-\mathrm{Mg} \mathrm{ha}^{-1}$ & & \\
\hline \multicolumn{5}{|c|}{ Aboveground biomass } \\
\hline Live biomass & 1.33 & 1.22 & 0.82 & 0.27 \\
\hline Dead biomass & 3.34 & 2.14 & 1.27 & 1.05 \\
\hline Total biomass & 4.67 & 3.36 & 2.09 & 1.18 \\
\hline \multicolumn{5}{|l|}{ Root biomass } \\
\hline $0-15 \mathrm{~cm}$ & 31.47 & 21.70 & 27.32 & 6.50 \\
\hline $15-30 \mathrm{~cm}$ & 5.52 & 6.97 & 5.29 & n.s. ${ }^{+}$ \\
\hline $30-60 \mathrm{~cm}$ & 1.62 & 1.78 & 1.16 & n.s. \\
\hline Total roots & 38.61 & 30.45 & 33.77 & n.s. \\
\hline Total plant biomass & 43.28 & 33.81 & 35.86 & n.s. \\
\hline
\end{tabular}

+ n.S., not significant.

wheatgrass represented $45 \%$ of the PSC (weight basis) in the CL grazing treatment, but only $21 \%$ in the $\mathrm{CH}$ grazing treatment; the contribution of blue grama increased from $17 \%$ of PSC in the CL to $27 \%$ under the $\mathrm{CH}$ treatment (Schuman et al., 1999). Even though the total PSC was similar for the EX and CL treatments, plant composition was quite different. Forbs were the dominant species group in the EX (33\%) but accounted for only 16 and $22 \%$ of the PSC in the CL and CH pastures, respectively (Schuman et al., 1999). Litter and standing dead together accounted for 72,63 , and $61 \%$ of the aboveground plant biomass in EX, CL, and $\mathrm{CH}$ pastures, respectively. Root biomass in the $0-$ to $15-\mathrm{cm}$ soil depth was significantly lower in the CL than EX and $\mathrm{CH}$ treatments, which did not differ. Coupland et al. (1960) and Dormaar and Willms (1990) determined that grazing significantly altered plant community composition in northern mixed-grass prairie, with a change from a $\mathrm{C}_{3}-$ to a $\mathrm{C}_{4}$-dominated community.

Carbon distribution in aboveground vegetation components (Table 11-2) responded similarly, as expected, to the vegetation component biomass (Table 11-1). Heavy grazing significantly reduced live biomass C, while both CL and CH treatments reduced dead biomass $C$. Mass of root $C$ in the $0-$ to $15-\mathrm{cm}$ depth was significantly greater in the EX than either of the grazing treatments. Greater root$\mathrm{C}$ mass and root biomass at the 0 - to $15-\mathrm{cm}$ depth may be due in part to the greater proportion of forbs found in the EX. Forbs have much larger diameter roots with greater biomass compared to grass roots.

Soil organic C mass in the 0 - to 30 -cm soil depth was significantly lower in EX than either of the grazed treatments (Table 11-3). Coupland and Van Dyne (1979) and Frank et al. (1995) found that blue grama partitioned more C belowground in blue grama-dominated systems than in mixed-grass prairie. Although there was no significant effect of grazing on total root biomass or root biomass below the 15-cm depth (Table 11-2), a slight increase in $\mathrm{C} / \mathrm{N}$ ratios (based on concentration data) of the root material was observed for the grazed treatments (CL 27:1, $\mathrm{CH} 28: 1)$ compared to the EX (24:1). This finding supports that forb roots present in the EX input less C compared to more fibrous root systems present in CL and 
Table 11-2. Carbon mass of vegetation components as affected by grazing in 1993. (Modified from Schuman et al., 1999.)

\begin{tabular}{|c|c|c|c|c|}
\hline Component & Exclosure & $\begin{array}{l}\text { Continuous } \\
\text { light grazing }\end{array}$ & $\begin{array}{l}\text { Continuous } \\
\text { heavy grazing }\end{array}$ & $\operatorname{LSD}(0.10)$ \\
\hline & 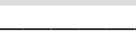 & $-\mathrm{MgCha}^{-1}$ & & \\
\hline \multicolumn{5}{|l|}{ Aboveground $\mathrm{C}$} \\
\hline Live biomass & 0.59 & 0.54 & 0.36 & 0.12 \\
\hline Dead biomass & 1.02 & 0.74 & 0.39 & 0.26 \\
\hline Total biomass & 1.61 & 1.28 & 0.75 & 0.25 \\
\hline \multicolumn{5}{|l|}{ Root C } \\
\hline $0-15 \mathrm{~cm}$ & 7.17 & 6.01 & 5.76 & 1.07 \\
\hline $15-30 \mathrm{~cm}$ & 1.24 & 1.65 & 1.31 & n.s. ${ }^{+}$ \\
\hline $30-60 \mathrm{~cm}$ & 0.38 & 0.50 & 0.35 & n.s. \\
\hline Total root C & 8.79 & 8.16 & 7.42 & n.s. \\
\hline Total plant C & 10.39 & 9.44 & 8.17 & 1.26 \\
\hline
\end{tabular}

+ n.s., not significant.

Table 11-3. Soil profile $\mathrm{C}$ mass and total system $\mathrm{C}$ mass of a grazed mixed-grass prairie in 1993. (Modified from Schuman et al., 1999.)

\begin{tabular}{ccccc} 
Depth increments & Exclosure & $\begin{array}{c}\text { Continuous } \\
\text { light grazing } \\
\text { Mg C ha-1 }\end{array}$ & $\begin{array}{c}\text { Continuous } \\
\text { heavy grazing }\end{array}$ & LSD(0.10) \\
\cline { 2 - 3 } Soil profile C & \multicolumn{3}{c}{} & \\
0-0.38 cm & 9.60 & 12.68 & 12.00 & 1.31 \\
$3.8-7.6 \mathrm{~cm}$ & 5.91 & 7.46 & 8.48 & 0.66 \\
$7.6-15 \mathrm{~cm}$ & 12.66 & 15.01 & 15.47 & 1.57 \\
$0-15 \mathrm{~cm}$ & 28.17 & 35.15 & 35.95 & 2.19 \\
$15-30 \mathrm{~cm}$ & 19.76 & 22.85 & 22.35 & 2.49 \\
$0-30 \mathrm{~cm}$ & 47.93 & 58.00 & 58.30 & 2.46 \\
$30-45 \mathrm{~cm}$ & 22.93 & 20.35 & 25.28 & n.s. ${ }^{\dagger}$ \\
$45-60 \mathrm{~cm}$ & 17.29 & 13.60 & 17.69 & n.s. \\
$0-60 \mathrm{~cm}$ & 88.15 & 91.95 & 101.27 & 11.85 \\
Total ecosystem C (includes plant component) & & \\
$0-30 \mathrm{~cm}$ & 57.94 & 66.94 & 66.12 & 4.33 \\
$0-60 \mathrm{~cm}$ & 98.54 & 101.39 & 109.44 & n.s. \\
\hline
\end{tabular}

+ n.s., not significant.

$\mathrm{CH}$ pastures. Frank et al. (1995) showed a similar, but nonsignificant, increase in $\mathrm{C} / \mathrm{N}$ ratio of the soil-root composite under grazed compared to the nongrazed exclosure. Their data also showed that grazing resulted in an increase in blue grama and $\delta^{13} \mathrm{C}$, which further substantiates that an increase in $\mathrm{C}$ inputs from $\mathrm{C}_{4}$ species contributed to the SOC pool. Dodd and Hopkins (1985) and Mutz and Drawe (1983) showed that simulated grazing increased aboveground production as well as root growth. Dyer and Bokhari (1976) suggested that simulated grazing may stimulate root respiration and root exudation. Increased belowground $\mathrm{C}$ in the grazed treatments was limited to the surface $30 \mathrm{~cm}$, where $>90 \%$ of the root biomass exists in these ecosystems. 
In our study, about 89 to $93 \%$ of ecosystem C in 1993 was stored in SOM at the 0 - to $60-\mathrm{cm}$ soil depth, with less than $10 \%$ found in vegetation components. Roots accounted for 85 to $91 \%$ of vegetation-component C. Therefore, the effect of grazing on aboveground plant components has limited potential impact on the total $\mathrm{C}$ mass of this system. However, grazing effects on plant growth and resource transfer to belowground components can significantly impact system $C$ distribution. Aboveground vegetation components have a greater potential to be photochemically oxidized (Coupland and Van Dyne, 1979) and lost from the system unless grazing breaks down plant material and encourages soil contact and/ or incorporation and decomposition.

Treatment responses of CER and soil respiration were similar from 1995 to 1997 (LeCain et al., 2000); therefore, for brevity, only the 1997 data are shown here. Early-season CER of the plant community in grazed treatments was as much as 50\% greater compared to the EX plant community (Fig. 11-1). Grazing-

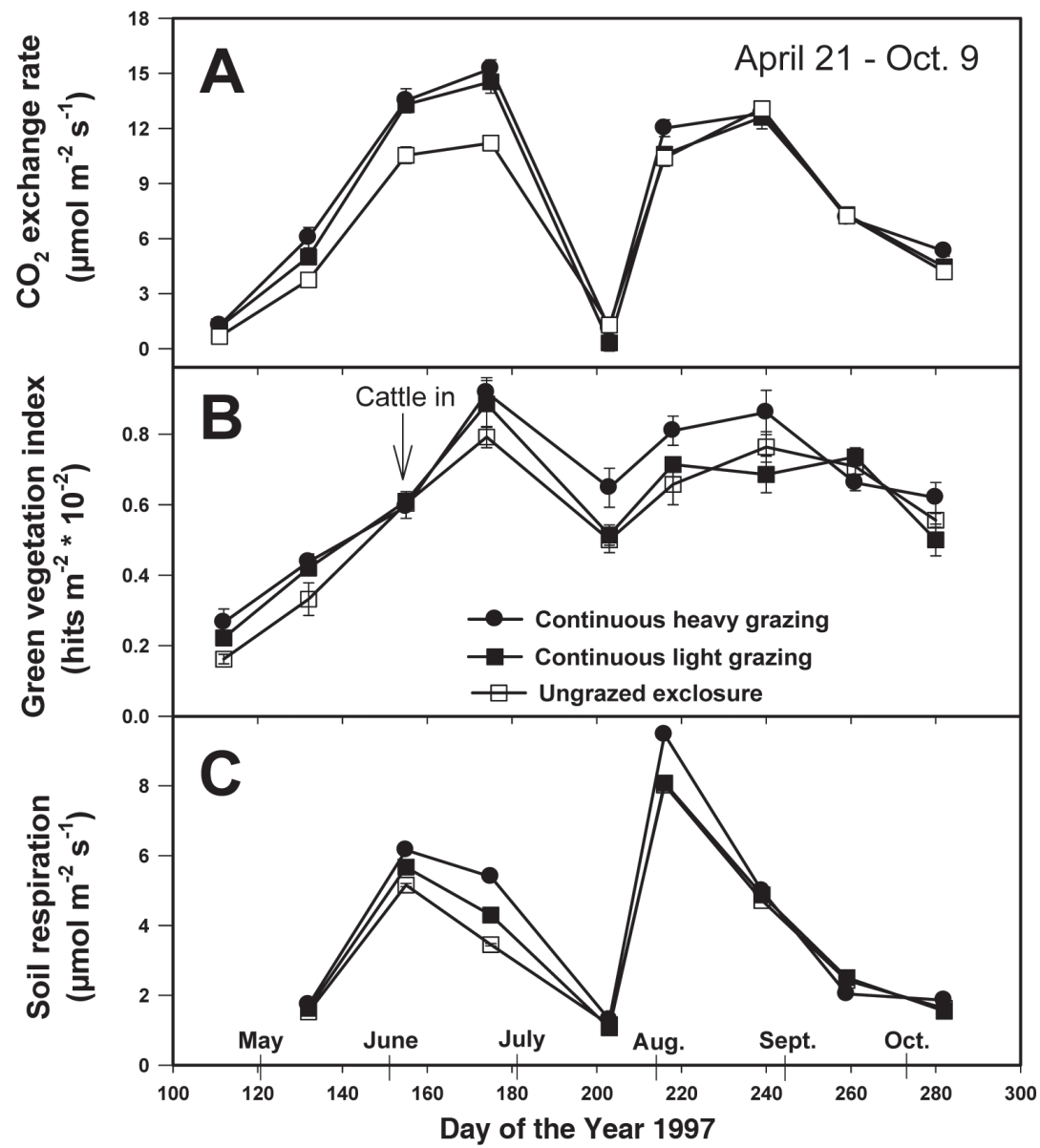

Fig. 11-1. $\mathrm{CO}_{2}$ exchange rate, green vegetation index, and soil respiration of three mixed-grass prairie pastures subjected to different grazing intensities, 1997. Data are means of five replications \pm standard error. (From LeCain et al., 2000.) 
induced greater CER was generally observed mid-April through the end of June and was closely related to GVI (Fig. 11-1). The CER and GVI data showed that grazing caused earlier and more vigorous growth, thereby resulting in a greater GVI and, hence, greater early-season photosynthesis. Even though LeCain et al. (2000) determined that average CER in the growing season was not significantly different between grazing treatments, the potential for greater aboveground production is almost always greater during the early growing season, when soil moisture and cool temperatures are more favorable for $\mathrm{C}_{3}$-dominated grasslands than during the latter warmer and typically drier portion of the growing season.

Eighty to $100 \%$ of PSC on the northern mixed prairie in southeastern Wyoming is typically achieved by June 30 (W.S. Johnson, unpublished data, 1984; D. Gasseling, unpublished data, 1998). Assuming that the accrual of new belowground plant $\mathrm{C}$ corresponds to aboveground growth, then production of new belowground tissues in the spring dominates seasonal growth rates, with belowground production limited during the latter half of the growing season. Derner and Hart (2007) reported aboveground production at this site was directly related to April through June precipitation. However, LeCain et al. (2000) found that if stored soil water does not become depleted, substantial photosynthesis can occur in these grasslands in the latter half of the growing season, and they speculated that much of this $\mathrm{C}$ may go to belowground plant organs. As perennial plants prepare for winter dormancy, they tend to partition more photosynthate to belowground storage compounds (Smith, 1973). The same mechanism apparently exists in cool-season grasses such as western wheatgrass as they enter the dry, hot days of summer (Morgan et al., 1998). However, rates often are limited by low available soil water, so the total amount of photosynthate available for translocation is usually limited. Further, because much of the $C$ that goes belowground at this time is converted to storage carbohydrates, most of it may be used in the regeneration of aboveground tissue, causing residence times in the soil to be quite short. For these reasons, we speculate that spring is generally the most important time for production of plant $C$ that has a significant residence time in soil. Because photosynthesis rates were high in grazed pastures during spring, this could account for a portion of the increased $C$ mass observed in the surface $30 \mathrm{~cm}$.

There also was a trend for greater soil respiration in the grazed compared to nongrazed treatment early in the season, particularly with heavy grazing (Fig. 11-1). Because CER is corrected for soil respiration, this is not a factor in the CER treatment differences. This indeed is another indication of greater biological activity during the early portion of the season with grazing. Reduction of litter and standing dead plant material (Table 11-1) most likely allows better light penetration to the soil, thereby creating warmer soil temperatures for plant growth and soil microbial activity.

Soil organic C levels in 2003, 21 yr after initiation of grazing treatments and 10 yr after the first assessment of SOC in this ecosystem, were significantly lower in the $\mathrm{CH}$ and EX treatments compared to the CL treatment for both the 0- to 30- and 30- to 60-cm soil depths (Table 11-4). These observed differences between the 1993 and 2003 sampling resulted in a significant loss (30\%) of SOC with heavy grazing.

Results of a lignin study conducted on the grazing treatments (Ganjegunte et al., 2005) showed that light grazing is beneficial compared to heavy grazing and nongrazing with respect to increased SOC and N contents. Stimulation of aboveground vegetation growth, better incorporation of aboveground plant 
Table 11-4. Soil organic $C$ mass under various grazing treatments (exclosure [EX], continuous light grazing $[\mathrm{CL}]$, continuous heavy grazing $[\mathrm{CH}]$ ) on northern mixed-grass prairie in Wyoming.

\begin{tabular}{|c|c|c|c|c|c|c|c|c|c|}
\hline \multirow[t]{2}{*}{$\begin{array}{l}\text { Soil } \\
\text { depth }\end{array}$} & \multicolumn{3}{|c|}{1993} & \multicolumn{3}{|c|}{2003} & \multicolumn{3}{|c|}{$\begin{array}{l}\text { Change from } 1993 \text { to } \\
2003\end{array}$} \\
\hline & EX & $C L$ & $\mathrm{CH}$ & EX & $C L$ & $\mathrm{CH}$ & EX & $C L$ & $\mathrm{CH}$ \\
\hline $\mathrm{cm}$ & &  & $-\mathrm{Mg}$ & $\mathrm{ha}^{-1}-$ & & - & - & $-\%$ & - \\
\hline $0-15$ & $28.2 b^{+}$ & $35.1 a$ & $35.9 a$ & $27.3 a$ & $32.0 \mathrm{a}$ & $26.0 a$ & -3 & -9 & $-28 \neq$ \\
\hline $0-30$ & $47.9 \mathrm{~b}$ & $58.0 \mathrm{a}$ & $58.3 a$ & $47.3 b$ & $54.2 \mathrm{a}$ & $42.5 b$ & -1 & -7 & $-27 \neq$ \\
\hline $0-60$ & $88.2 b$ & 91.9ab & $101.4 a$ & $80.5 b$ & $92.5 a$ & $70.5 b$ & -9 & +1 & $-30 \neq$ \\
\hline
\end{tabular}

+ Different lower case letters indicate significant differences between grazing treatments (within a year and soil depth), $p \leq 0.10$.

‡ Significant difference in $C$ mass between years, $p \leq 0.10$.

residues, and increased decomposition rates of plant residues within the CL treatment resulted in increased SOM contents. The $\mathrm{CuO}$ oxidation analysis of soil and humic substances indicated that lignin in soil of all treatments comprised primary lignin units resulting from vegetation impacts on SOM composition. Grazing intensity increased the breakdown of lignin, with enhanced lignin degradation in the grazing treatments probably due to partial decomposition of plant material by livestock, as well as the resultant defecated material that is more susceptible to decomposition, physical breakdown of plant residues due to trampling, and increased contact with soil or partial burying of plant residues due to hoof action.

Since inception of the grazing treatments, significant changes in plant community composition and productivity have occurred. Cool-season $\left(\mathrm{C}_{3}\right)$ plant production in the $\mathrm{CH}$ treatment declined by nearly $50 \%$ compared to EX and CL grazing treatments (EX, 62\% of total production; $\mathrm{CL}, 64 \%$; $\mathrm{CH}, 33 \%$; 2004 vegetation data; J.D. Derner, unpublished data, 2006). The primary $\mathrm{C}_{4}$ grass, blue grama, has become increasingly more dominant, representing $42 \%$ of the total production in the $\mathrm{CH}$ compared to $4 \%$ in EX and 11\% in CL treatment (2004 vegetation data; J.D. Derner, unpublished data, 2006). Derner and Hart (2007) reported a 29\% reduction in total aboveground biomass on the $\mathrm{CH}$ compared to CL from 1991 to 2005 due to the shift in plant community composition. As noted earlier, the $\mathrm{C}_{3}$ grasses represent $55 \%$ of the productivity in this northern mixed-grass rangeland ecosystem, with the growth cycle of the grasses being very similar to the precipitation patterns of the area (Derner and Hart, 2007). The shift from a plant community dominated by $\mathrm{C}_{3}$ species to one dominated by $\mathrm{C}_{4}$ species (blue grama) resulted in a major change in root biomass distribution. Whereas the majority of perennial grass roots are in the top $30 \mathrm{~cm}$ of the soil at this site, a significant proportion of western wheatgrass roots can extend well beyond the $30-\mathrm{cm}$ soil depth to $80 \mathrm{~cm}$ and deeper, where blue grama roots are scarce (Weaver and Darland, 1949; Coupland and Johnson, 1965; LeCain et al., 2006). Thus, heavy grazing, which encourages blue grama at the expense of western wheatgrass, induces a grassland with a proportionally higher percentage of shallow compared to deep roots, making them more susceptible to decomposition and change in climatic conditions that influence decomposition. Although the redistribution of SOC in the soil profile can enhance the SOC in near-surface soils (Schuman et al., 1999), it may also result in more rapid $\mathrm{C}$ cycling and loss under some environmental conditions (e.g., drought). 
Table 11-5. Annual and April through June precipitation ( $\mathrm{mm}$ ) at High Plains Grasslands Research Station, Cheyenne, Wyoming, 1982 to 2003.

\begin{tabular}{l|c|c|c|}
\multicolumn{1}{c|}{ Years } & April-June & Annual & Years 75\% of Meant \\
\hline $1982-1993$ & 195.4 & 476.7 & 1 \\
$1994-2003$ & 163.7 & 373.9 & 5 \\
$1994,1998,2000-2002$ & 107.7 & 286.5 & \\
$1977-2003$ & 178.3 & 428.0 & 6
\end{tabular}

$+1977-2003$ average annual precipitation used for these values.

Bellamy et al. (2005) reported losses of SOC due to variations in precipitation and temperature. They postulated that drier, warmer soils have a greater potential for aeration, which increases microbial respiration and decomposition. From 1994 to 2003, several years of moderate to severe drought occurred at our research site (Table 11-5), and soil temperatures at the 5- and 10-cm depth showed a general increase from 1982 to 2003, even though the average air temperature did not exhibit this increase (Fig. 11-2). LeCain et al. (2000) and Bremer et al. (2001) found that grazing resulted in higher soil temperatures, which have been associated with a loss of SOC to the atmosphere (Sukyer and Verma, 2001). Measurements of $\mathrm{CO}_{2}$ flux at a shortgrass rangeland site (Central Plains Experimental Range) about $40 \mathrm{~km}$ south of the High Plains Grasslands Research Station showed significant $\mathrm{CO}_{2}$ release to the atmosphere from a heavily grazed pasture during these same

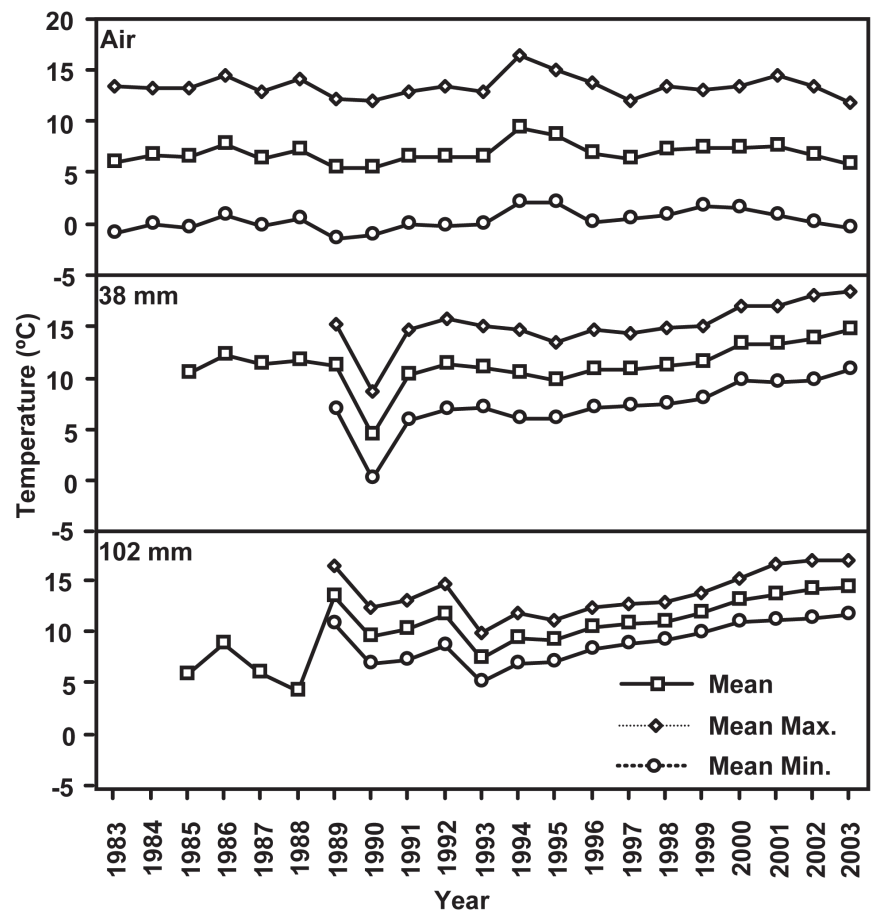

Fig. 11-2. Annual mean (Mean), maximum (Max.), and minimum (Min.) air and soil (38- and 102-mm depths) temperatures at the High Plains Grasslands Research Station, Cheyenne, Wyoming. (From Ingram et al., 2008.) 
drought years (Morgan et al., 2004), further supporting our measured loss of SOC from the $\mathrm{CH}$ grazed treatment.

Our research showed that proper grazing does not adversely affect $C$ resources of this rangeland ecosystem and, in fact, showed an increase in soil-C mass associated with the surface $30 \mathrm{~cm}$ of soil, which is the most active portion of the soil profile as it relates to root growth and microbial activity. The increase in SOC observed is believed to be the result of several factors: enhanced incorporation and decomposition of litter and standing dead through hoof action of grazing animals, transfer of net primary production to belowground plant parts, increased plant vigor, changed plant community composition (fewer forbs and more perennial grass), and increased plant vigor during the early growing season (exhibited by increased CER and GVI). Increased SOC in the 0- to 30-cm zone has important implications for management and potential $\mathrm{C}$ sequestration in these grasslands. These rangeland ecosystems developed under grazing by large herbivores, and removing livestock from these ecosystems could over the long term reduce SOC and the productivity and sustainability of these lands (Milchunas et al., 1988). However, grazing at levels that impact plant community composition can significantly reduce the production and resilience of northern mixed-grass prairies. The major change in plant community composition observed on our study site provided conditions that made this system susceptible to SOC losses during drought and associated increased soil temperatures.

\section{Acknowledgments}

The authors would like to thank Jean D. Reeder and Dan R. LeCain who participated in the earlier phase of this research; Girisha Ganjegunte for research conducted during the 2003 field season; and Ernie Taylor, Matt Mortenson, Jeremy Manley, and Pam Freeman for their able field and laboratory assistance. The authors also acknowledge and thank Douglas Johnson and Steve Del Grosso for review of this manuscript. This is a contribution from the Rangeland Resources Research Unit, USDA, ARS.

\section{References}

Bauer, A., C.V. Cole, and A.L. Black. 1987. Soil property comparisons in virgin grasslands between grazed and nongrazed management systems. Soil Sci. Soc. Am. J. 51:176-182.

Bellamy, P.H., P.J. Loveland, R.I. Bradley, R.M. Lark, and G.J.D. Kirk. 2005. Carbon losses from all soils across England and Wales 1978-2003. Nature 437:245-248.

Blake, G.R., and K.H. Hartge. 1986. Bulk density-core method. p. 363-375. In A. Klute (ed.) Methods of soil analysis, Part 1. 2nd ed. Agron. Monogr. No. 9. ASA, Madison, WI.

Bremer, D.J., L.M. Auen, J.M. Ham, and C.E. Owensby. 2001. Evapotranspiration in a prairie ecosystem: Effects of grazing by cattle. Agron. J. 93:338-348.

Christie, E.K. 1979. Ecosystem processes in semiarid grasslands: II. Litter production, decomposition and nutrient dynamics. Aust. J. Agric. Res. 30:29-42.

Coupland, R.T. 1992. Mixed prairie. p. 151-182. In R.T. Coupland (ed.) Ecosystems of the world, 8A. Natural grasslands: Introduction and Western Hemisphere. Elsevier, New York.

Coupland, R.T., and R.E. Johnson. 1965. Rooting characteristics of native grassland species in Saskatchewan. J. Ecol. 53:475-507.

Coupland, R.T., N.A. Skoglund, and A.J. Heard. 1960. Effects of grazing in the Canadian mixed prairie. p. 212-215. In Proc. 8th International Grassland Congress. 11-21 July 1960, Univ. of Reading, Reading, England. Alden Press, Oxford.

Coupland, R.T., and G.M. VanDyne. 1979. Systems synthesis. p. 97-106. In R.T. Coupland (ed.) Grassland ecosystems of the world: Analysis of grasslands and their uses. International Biological Programme, 18. Cambridge Univ. Press, Cambridge.

Davidson, R.L. 1978. Root systems—the forgotten component of pastures. p. 86-94. In J.R. Wiklson (ed.) Plant relations in pastures. CSIRO, East Melbourne, Australia. 
Derner, J.D., and R.H. Hart. 2007. Grazing-induced modifications to peak standing crop in northern mixed-grass prairie. Rangeland Ecol. Manage. 60:270-276.

Detling, J.K., M.I. Dyer, and D.T. Winn. 1979. Net photosysnthesis, root respiration and regrowth of Bouteloua gracilis following simulated grazing. Oecologia 41:127-134.

Dodd, J.D., and H.H. Hopkins. 1985. Yield and carbohydrate content of blue grama as affected by clipping. Trans. Kans. Acad. Sci. 61:282-287.

Dormaar, J.F., and W.D. Willms. 1990. Effect of grazing and cultivation on some chemical properties of soils in the mixed prairie. J. Range Manage. 43:456-460.

Dyer, M.I., and U.G. Bokhari. 1976. Plant-animal interactions: Studies of the effects of grasshopper grazing on blue grama grass. Ecology 57:762-772.

Frank, A.B., D.L. Tanaka, L. Hofmann, and R.F. Follett. 1995. Soil carbon and nitrogen of Northern Great Plains grasslands as influenced by long-term grazing. J. Range Manage. 48:470-474.

Ganjegunte, G.K., G.F. Vance, C.M. Preston, G.E. Schuman, L.J. Ingram, P.D. Stahl, and J.M. Welker. 2005. Influence of different grazing management practices on soil organic carbon constituents in a northern mixed-grass prairie. Soil Sci. Soc. Am. J. 69:1746-1756.

Hart, R.H., M.J. Samuel, P.S. Test, and M.A. Smith. 1988. Cattle, vegetation, and economic responses to grazing systems and grazing pressure. J. Range Manage. 41:282-286.

Holland, E.A., and J.K. Detling. 1990. Plant response to herbivory and belowground nitrogen cycling. Ecology 71:1040-1049.

Ingram, L.J., P.D. Stahl, G.E. Schuman, J. Buyer, G.F. Vance, G.K. Ganjegunte, J.W. Welker, and J.D. Derner. 2008. Grazing impacts on soil carbon and microbial communities in a mixed-grass ecosystem. Soil Sci. Soc. Am. J. 72:939-948.

Jones, M.B., and A. Donnelly. 2004. Carbon sequestration in temperate grassland ecosystems and the influence of management, climate, and elevated $\mathrm{CO}_{2}$. New Phytol. 164:423-439.

Kaiser, J. 2000. Panel estimates possible "C" sinks. Science 288:942-943.

Kögel, I., and R. Böchter. 1985. Characterization of lignin in forest humus layers by high-performance liquid chromatography of cupric oxide oxidation products. Soil Biol. Biochem. 17:637-640.

Kögel-Knabner, I., P.G. Hatcher, and W. Zech. 1991. Chemical structural studies of forest soil humic acids: Aromatic carbon fraction. Soil Sci. Soc. Am. J. 55:241-247.

Lauenroth, W.K., and W.C. Whittman. 1971. A rapid method for washing roots. J. Range Manage. 24:308-309.

LeCain, D.R., J.A. Morgan, D.G. Milchunas, A.R. Mosier, J.A. Nelson, and D.P. Smith. 2006. Root biomass of individual species, and root characteristics after five years of $\mathrm{CO}_{2}$ enrichment on native shortgrass steppe. Plant Soil 279:219-228.

LeCain, D.R., J.A. Morgan, G.E. Schuman, J.D. Reeder, and R.H. Hart. 2000. Carbon exchange rates in grazed and ungrazed pastures of Wyoming. J. Range Manage. 53:199-206.

Milchunas, D.G., and W.K. Lauenroth. 1993. Quantitative effects of grazing on vegetation and soils over a global range of environments. Ecol. Monogr. 63:327-366.

Milchunas, D.G., V.E. Sala, and W.K. Lauenroth. 1988. A generalized model of the effects of grazing by large herbivores on grassland community structure. Am. Nat. 132:87-106.

Morgan, J.A., D.R. LeCain, J.J. Read, H.W. Hunt, and W.G. Knight. 1998. Photosynthetic pathway and ontogeny affect water relations and the impact of $\mathrm{CO}_{2}$ on Bouteloua gracilis $\left(\mathrm{C}_{4}\right)$ and Pascopyrum smithii $\left(C_{3}\right)$. Oecologia 114:483-493.

Morgan, J.A., D.R. LeCain, J.D. Reeder, G.E. Schuman, J.D. Derner, W.K. Lauenroth, W.J. Parton, and I.C. Burke. 2004. Drought and grazing impacts on $\mathrm{CO}_{2}$ fluxes in the Colorado shortgrass steppe. $\mathrm{p}$. 359. In Abstracts of the 89th Annual Meeting of the Ecological Society of America, Portland, OR. ESA, Washington, DC.

Mutz, J.L., and D.L. Drawe. 1983. Clipping frequency and fertilization influence herbage yield and crude protein content of four grasses in south Texas. J. Range Manage. 36:582-585.

Naeth, M.A., A.W. Bailey, D.J. Pluth, D.S. Chanasyk, and R.T. Hardon. 1991. Grazing impacts on litter and soil organic matter in mixed prairie and fescue grassland ecosystems in Alberta. J. Range Manage. 44:7-12.

National Oceanic and Atmospheric Administration (NOAA). 1994. Local climatological data, Cheyenne, Wyoming. National Climate Data Center, Ashville, NC.

Nelson, D.W., and L.E. Sommers. 1982. Total carbon, organic carbon, and organic matter. p. 539-581. In A.L. Page, R.H. Miller, and D.R. Keeney (ed.) Methods of soil analysis, Part 1. 2nd ed. Agron. Monogr. No. 9. ASA, Madison, WI. 
Parton, W.J., J.A. Morgan, R.H. Kelly, and D.S. Ojima. 2000. Modeling soil C responses to environmental change in grassland systems. p. 371-398. In R.F. Follett et al. (ed.) The potential of U.S. grazing lands to sequester carbon and mitigate the greenhouse effect. Lewis Publ., New York.

Power, J.F. 1994. Understanding the nutrient cycling process. J. Soil Water Conserv. 49:16-23.

Schuman, G.E., J.D. Reeder, J.T. Manley, R.H. Hart, and W.A. Manley. 1999. Impact of grazing management on the carbon and nitrogen balance of a mixed-grass rangeland. Ecol. Applic. 9:65-71.

Schuster, J.L. 1964. Root development of native plants under three grazing intensities. Ecology 45:63-70.

Shariff, A.R., M.E. Biondini, and C.E. Grygiel. 1994. Grazing intensity effects on litter decomposition and soil nitrogen mineralization. J. Range Manage. 47:444-449.

Sherrod, L.A., G. Dunn, G.A. Peterson, and R.L. Kolberg. 2002. Inorganic carbon analysis by modified pressure-calcimeter method. Soil Sci. Soc. Am. J. 66:299-305.

Smith, D. 1973. Physiological consideration in forage management. p. 425-436. In M.E. Heath, D.S. Metcalfe, and R.F Barnes (ed.) Forages. Iowa State Univ. Press, Ames.

Smoliak, S., J.F. Dormaar, and A. Johnston. 1972. Long-term grazing effects on Stipa-Bouteloua prairie soils. J. Range Manage. 25:246-250.

Stevenson, A., R.E. Baumgartner, and G.E. Schuman. 1984. High Plains Grasslands Research Station, detailed soil survey. 1-84/1C/3.62. USDA, ARS, Cheyenne WY, USDA, SCS, Casper, WY, and Wyoming Agric. Exp. Stn., Laramie, WY.

Sukyer, A.E., and S.B. Verma. 2001. Year-round observations of the net ecosystem exchange of carbon dioxide in a native tallgrass prairie. Global Change Biol. 7:279-289.

Warren-Wilson, J. 1963. Estimation of foliage denseness and foliage angle by inclined point quadrats. Aust. J. Bot. 11:95-105.

Weaver, J.E., and R.W. Darland. 1949. Soil-root relationships of certain native grasses in various soil types. Ecol. Monogr. 19:303-338. 